\title{
Synthesis and Properties of Green Sustainable Carbonate-type Nonionics Containing Polyoxyethylene Chains
}

\author{
Taisuke Banno, Hiroshi Sato, Takayuki Tsuda and Shuichi Matsumura* \\ Department of Applied Chemistry, Faculty of Science and Technology, Keio University (3-14-1, Hiyoshi, Kohoku-ku, Yokohama 223-8522, \\ JAPAN)
}

\begin{abstract}
A series of polyoxyethylene surfactants containing carbonate linkages as biodegradable and chemically recyclable segments was designed and synthesized by a green process. A two-step carbonate exchange reaction was used: dimethyl or diphenyl carbonate was reacted with 1-alkanol, and the product was reacted with poly (ethylene) glycol in the presence of a lipase or chemical catalyst. The obtained carbonate-type nonionics exhibited good surface-active properties such as a low critical micelle concentration value and a surface tension lowering action. They were readily biodegraded by activated sludge, furthermore, could be chemical recycled using a lipase.
\end{abstract}

Key words: biodegradability, carbonate linkage, chemical recycling, green surfactant, surface activity

\section{INTRODUCTION}

The greening of chemistry requires the discovery and development of new synthetic routes that rely only on renewable feedstocks, the identification of reaction conditions and catalysts that afford improved selectivity and energy efficiency, and the design of bio/environmentally compatible chemicals. For the production of surfactants, the use of renewable bio-based materials is very important from the standpoint of global sustainability. Thus the replacement of petroleum derived raw materials with renewable bio-based resources is required. Based on these concepts, some green surfactants have been designed and synthesized using bio-based or potentially bio-based starting materials, such as amino acids, fumaric acid, maleic acid, and aconitic acid ${ }^{1-3)}$.

Due to the water-soluble nature of surfactants, they are generally difficult to recover or reuse. Therefore, they are discharged as drainage into the environment and are widely diffused if they are not biodegradable. Thus, the development of biodegradable surfactants is required with respect to environmental issues. It has been reported that biodegradable and cleavable nonionics containing a hydrolyzable linkage, such as an ester ${ }^{4,5)}$ or amide ${ }^{6)}$, have been designed and synthesized. Also, gemini-type cationics containing ester linkages in the hydrophobic moiety were bio- degraded by activated sludge ${ }^{7-9)}$. However, ester linkages are generally labile to hydrolysis, particularly under alkaline conditions. More hydrolytically stable surfactants are needed. Furthermore, even water-soluble surfactants should be chemically recycled as much as possible in order to establish their sustainability in the industrial field.

The carbonate linkage is hydrolyzed in aqueous media by lipase to produce two hydroxyl groups along with the evolution of carbon dioxide. It is advantageous for surfactants that, in the absence of lipase, the carbonate linkages are more stable in aqueous media as compared to ester linkages, because they are generally used in an aqueous solution. Carbonate-type nonionics containing a polyoxyethylene chain were first reported by Stjerndahl et $a l{ }^{10)}$. Carbonate-type nonionics having both a hydrolytic stability and biodegradability were synthesized by the reaction of octanoyl chloroformate with tetra (ethylene glycol) in the presence of pyridine in dichloromethane. A more environmentally benign synthetic route is required in terms of green sustainable chemistry. We previously reported that biodegradable and chemically recyclable single-type and gemini-type cationics containing carbonate linkages were designed and synthesized by a green process. The $n$-alkyl dimethylaminopropyl carbonate as a synthetic intermediate of the cationics was prepared by the two-step succes-

\footnotetext{
*Correspondence to: Shuichi Matsumura, Department of Applied Chemistry, Faculty of Science and Technology, Keio University, 3-14-1, Hiyoshi, Kohoku-ku, Yokohama 223-8522, JAPAN

E-mail: matumura@applc.keio.ac.jp

Accepted August 16, 2010 (received for review July 15, 2010)

Journal of Oleo Science ISSN 1345-8957 print / ISSN 1347-3352 online

http://www.jstage.jst.go.jp/browse/jos/
} 


\section{T. Banno, H. Sato, T. Tsuda and S. Matsumura}

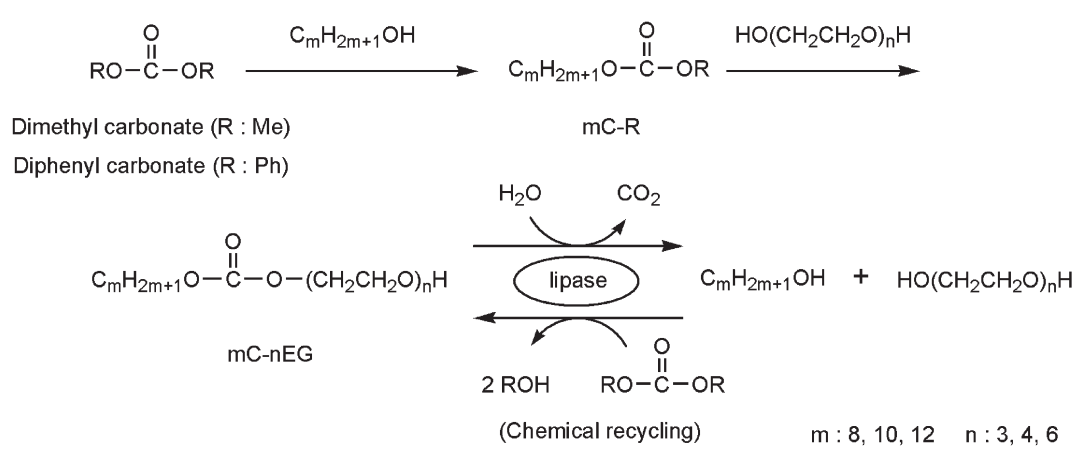

Scheme 1 Synthesis and chemical recycling of $\mathrm{mC}-\mathrm{nEG}$

sive carbonate exchange reaction of diphenyl carbonate with 1-alkanol followed by a reaction with $N, N$-dimethylaminopropanol $^{11)}$. Diphenyl carbonate is now industrially produced by the carbonate exchange reaction of dimethyl carbonate with phenol. Dimethyl carbonate can be produced from methanol and carbon dioxide by a green meth$\operatorname{od}^{12-14)}$.

In this report, biodegradable and chemically recyclable carbonate-type nonionics containing a polyoxyethylene chain were designed and synthesized by the two-step carbonate exchange reaction of dimethyl or diphenyl carbonate with 1-alkanol followed by the reaction of poly (ethylene glycol) as shown in Scheme 1. Their surfactant properties, biodegradabilities, and chemical recyclabilities were then evaluated.

\section{EXPERIMENTAL PROCEDURES}

\subsection{Materials and methods}

Dimethyl carbonate, diphenyl carbonate, 1-alkanol, and dodecanoyl chloride were purchased from Tokyo Kasei Kogyo Co., Ltd. (Tokyo, Japan), and used as received. Tri (ethylene glycol), tetra (ethylene glycol) and hexa (ethylene glycol) were purchased from Junsei Chemical Co., Ltd. (Tokyo, Japan). $\mathrm{K}_{2} \mathrm{CO}_{3}$ was purchased from Kanto Chemical Co., Inc. (Tokyo, Japan) and dried under vacuum before use. Triethylamine $\left(\mathrm{Et}_{3} \mathrm{~N}\right)$ and dodecyl tetra (oxyethylene) ether (12Et-4EG) were purchased from Wako Pure Chemical Industries, Ltd. (Tokyo, Japan). Immobilized lipase from Candida antarctica [lipase CA: Novozym 435, a lipase (lipase B) from Candida antarctica produced by submerged fermentation of a genetically modified Aspergillus oryzae microorganism and adsorbed on a macroporous acrylic resin, having 10,000 PLU/g (propyl laurate units: lipase activity based on ester synthesis)] was kindly supplied by Novozymes Japan Ltd. (Chiba, Japan). Lipase from Candida rugosa (CR) and lipase from porcerin pancreas were purchased from Aldrich Chemical Co. (Milwaukee, WI, USA). Lipase from Pseudomonas sp. (PS) was purchased from
Amano Pharmaceutical Co., Ltd (Nagoya, Japan). The enzyme was dried under vacuum $(3 \mathrm{mmHg})$ over $\mathrm{P}_{2} \mathrm{O}_{5}$ at $25^{\circ} \mathrm{C}$ for $2 \mathrm{~h}$ before use. Thermally deactivated lipase CA was prepared by heating the enzyme in steam using an autoclave at $120^{\circ} \mathrm{C}$ for $15 \mathrm{~min}$ and subsequent freeze-drying in vacuum. The purity and chemical structure of the synthesized compounds were analyzed by thin-layer chromatography (TLC), elemental analysis, and ${ }^{1} \mathrm{H}$ NMR spectroscopy. TLC was carried out using Merck silica gel $60 \mathrm{~F}_{254}$ plates (Merck Ltd., Darmstadt, Germany). ${ }^{1} \mathrm{H}$ NMR spectra were recorded with a Lambda 300 Fourier Transform Spectrometer (JEOL Ltd., Tokyo, Japan) operating at 300 MHz. Carbonate and ester-type nonionics were analyzed by size exclusion chromatography (SEC) using SEC columns (Shodex K-803L + K-806L + K-800D, Showa Denko Co., Ltd., Tokyo, Japan) with a refractive index detector. Chloroform was used as the eluent at a flow rate of $1.0 \mathrm{~mL} / \mathrm{min}$.

\subsection{Preparation of $n$-alkyl phenyl carbonate ( $\mathrm{mC}-\mathrm{Ph}$ )}

The $\mathrm{mC}-\mathrm{Ph}$ was prepared by the carbonate exchange reaction of diphenyl carbonate with 1-alkanol in the presence of $\mathrm{Et}_{3} \mathrm{~N}$ according to Scheme 1. The following is representative of a typical procedure. A mixture of diphenyl carbonate (428.4 mg, $2.0 \mathrm{mmol}$ ), 1-dodecanol (372.6 mg, 2.0 $\mathrm{mmol}$ ), and $\mathrm{Et}_{3} \mathrm{~N}$ (202.4 mg, $2.0 \mathrm{mmol}$ ) was stirred under an argon atmosphere at $70^{\circ} \mathrm{C}$ for $15 \mathrm{~h}$. After the reaction, the $\mathrm{Et}_{3} \mathrm{~N}$ was evaporated under reduced pressure. The residue was then purified by silica gel column chromatography $(n-$ hexane/ethyl acetate/acetone $=20 / 1 / 1$ [by vol], $\left.R_{f}=0.50\right)$ to obtain $12 \mathrm{C}-\mathrm{Ph}$ in $87 \%$ yield as a colorless syrup. The molecular structure was analyzed by ${ }^{1} \mathrm{H}$ NMR spectroscopy and elemental analysis. In a similar procedure, 8C-Ph and 10C-Ph were prepared using 1-octanol and 1-decanol, respectively. Their yields and elemental analysis are summarized in Table 1.

8C-Ph: ${ }^{1} \mathrm{H}$ NMR $\left(300 \mathrm{MHz}, \mathrm{CDCl}_{3}\right): \delta=0.88(3 \mathrm{H}, \mathrm{t}, J=7.2$ $\left.\mathrm{Hz}, \mathrm{CH}_{3^{-}}\right), 1.18-1.50\left(10 \mathrm{H}, \mathrm{m},-\left(\mathrm{CH}_{2}\right)_{5}{ }^{-}\right), 1.74(2 \mathrm{H}, \mathrm{tt}, J=$ $\left.7.1,7.1 \mathrm{~Hz},-\mathrm{CH}_{2}-\mathrm{CH}_{2}-\mathrm{O}-\right), 4.24\left(2 \mathrm{H}, \mathrm{t}, J=6.6 \mathrm{~Hz},-\mathrm{CH}_{2}-\mathrm{O}\right)$, 7.12-7.52 (5H, m, Ph-). 
Table 1 Synthesis and analytical data of $\mathrm{mC}-\mathrm{Ph}$

\begin{tabular}{ccccccc}
\hline \multirow{2}{*}{ Compound } & $\mathrm{C}_{\mathrm{m}} \mathrm{H}_{2 \mathrm{~m}+1}$ & Yield & \multicolumn{2}{c}{$\mathrm{C} \%$} & \multicolumn{2}{c}{$\mathrm{H} \%$} \\
& $\mathrm{~m}$ & $(\%)$ & Found & Calcd. & Found & Calcd. \\
\hline $8 \mathrm{C}-\mathrm{Ph}$ & 8 & 80 & 71.83 & 71.97 & 8.94 & 8.86 \\
$10 \mathrm{C}-\mathrm{Ph}$ & 10 & 74 & 73.12 & 73.34 & 9.29 & 9.41 \\
$12 \mathrm{C}-\mathrm{Ph}$ & 12 & 87 & 74.42 & 74.47 & 9.90 & 9.87 \\
\hline
\end{tabular}

10C-Ph: ${ }^{1} \mathrm{H}$ NMR $\left(300 \mathrm{MHz}, \mathrm{CDCl}_{3}\right): \delta=0.88(3 \mathrm{H}, \mathrm{t}, J=$ $\left.7.2 \mathrm{~Hz}, \mathrm{CH}_{3^{-}}\right), 1.16-1.50\left(14 \mathrm{H}, \mathrm{m},-\left(\mathrm{CH}_{2}\right)_{7^{-}}\right), 1.74(2 \mathrm{H}, \mathrm{tt}, J$ $\left.=7.1,7.1 \mathrm{~Hz},-\mathrm{CH}_{2}-\mathrm{CH}_{2}-\mathrm{O}-\right), 4.24(2 \mathrm{H}, \mathrm{t}, J=6.6 \mathrm{~Hz}$, $\left.-\mathrm{CH}_{2}-\mathrm{O}\right), 7.12-7.44(5 \mathrm{H}, \mathrm{m}, \mathrm{Ph}-)$.

12C-Ph: ${ }^{1} \mathrm{H}$ NMR $\left(300 \mathrm{MHz}, \mathrm{CDCl}_{3}\right): \delta=0.88(3 \mathrm{H}, \mathrm{t}, J=$ $\left.7.2 \mathrm{~Hz}, \mathrm{CH}_{3^{-}}\right), 1.18-1.52\left(18 \mathrm{H}, \mathrm{m},-\left(\mathrm{CH}_{2}\right)_{9^{-}}\right), 1.74(2 \mathrm{H}, \mathrm{tt}, J$ $\left.=7.1,7.1 \mathrm{~Hz},-\mathrm{CH}_{2}-\mathrm{CH}_{2}-\mathrm{O}-\right), 4.25(2 \mathrm{H}, \mathrm{t}, J=6.6 \mathrm{~Hz}$, $\left.-\mathrm{CH}_{2}-\mathrm{O}\right), 7.15-7.45(5 \mathrm{H}, \mathrm{m}, \mathrm{Ph}-)$.

\subsection{Preparation of carbonate-type nonionics containing polyoxyethylene chain ( $\mathrm{mC}-\mathrm{nEG}$ )}

The mC-nEG was prepared by the carbonate exchange reaction of $\mathrm{mC}-\mathrm{Ph}$ with poly (ethylene glycol) in the presence of lipase or a chemical catalyst according to Scheme 1. The following represents a typical procedure. A mixture of $12 \mathrm{C}-\mathrm{Ph}(459.6 \mathrm{mg}, 1.5 \mathrm{mmol}$ ), tetra (ethylene glycol) (582.0 mg, $3.0 \mathrm{mmol})$, and $\mathrm{K}_{2} \mathrm{CO}_{3}(91.9 \mathrm{mg}, 20 \mathrm{wt} \%$ relative to $12 \mathrm{C}-\mathrm{Ph}$ ) in dry acetone (the concentration of $12 \mathrm{C}-\mathrm{Ph}$ was $300 \mathrm{mg} / \mathrm{mL}$ ) was stirred under an argon atmosphere at room temperature for $24 \mathrm{~h}$. After the reaction, $\mathrm{K}_{2} \mathrm{CO}_{3}$ was removed by filtration, and the solvent was evaporated under reduced pressure. The residue was then purified by silica gel column chromatography $(n$-hexane/acetone $=4 / 1, \mathrm{v} /$ $\left.\mathrm{v}, R_{f}=0.15\right)$ to obtain $12 \mathrm{C}-4 \mathrm{EG}$ in $70 \%$ yield as a colorless syrup. The molecular structure was analyzed by ${ }^{1} \mathrm{H}$ NMR spectroscopy and elemental analysis. In a similar procedure, a series of mC-nEG was prepared in $66-80 \%$ yield. Their yields and elemental analyses are summarized in Table 2.

8C-4EG: ${ }^{1} \mathrm{H}$ NMR $\left(300 \mathrm{MHz}, \mathrm{CDCl}_{3}\right): \delta=0.86(3 \mathrm{H}, \mathrm{t}, J=$ $\left.6.8 \mathrm{~Hz}, \mathrm{CH}_{3^{-}}\right), 1.21-1.42\left(10 \mathrm{H}, \mathrm{m},-\left(\mathrm{CH}_{2}\right)_{5^{-}}\right), 1.64(2 \mathrm{H}, \mathrm{tt}, J$ $\left.=6.8,6.8 \mathrm{~Hz},-\mathrm{CH}_{2}-\mathrm{CH}_{2}-\mathrm{O}-\right)$, 3.58-3.80 (14H, m, 7- $\left.\mathrm{CH}_{2}-\mathrm{O}-\right)$, $4.14\left(2 \mathrm{H}, \mathrm{t}, J=6.6 \mathrm{~Hz},-\mathrm{OC}(=\mathrm{O}) \mathrm{O}-\mathrm{CH}_{2^{-}}\right), 4.24-4.34(2 \mathrm{H}, \mathrm{m}$, $\left.-\mathrm{OC}(=\mathrm{O}) \mathrm{O}-\mathrm{CH}_{2^{-}}\right)$.

10C-4EG: ${ }^{1} \mathrm{H} \mathrm{NMR}\left(300 \mathrm{MHz}, \mathrm{CDCl}_{3}\right): \delta=0.88(3 \mathrm{H}, \mathrm{t}, J=$ $\left.6.8 \mathrm{~Hz}, \mathrm{CH}_{3^{-}}\right), 1.20-1.44\left(14 \mathrm{H}, \mathrm{m},-\left(\mathrm{CH}_{2}\right)_{7^{-}}\right), 1.64(2 \mathrm{H}, \mathrm{tt}, J$ $\left.=6.8,6.8 \mathrm{~Hz},-\mathrm{CH}_{2}-\mathrm{CH}_{2}-\mathrm{O}-\right)$, 3.58-3.80 (14H, m, 7- $\left.\mathrm{CH}_{2}-\mathrm{O}-\right)$, $4.14\left(2 \mathrm{H}, \mathrm{t}, J=6.3 \mathrm{~Hz},-\mathrm{OC}(=\mathrm{O}) \mathrm{O}-\mathrm{CH}_{2^{-}}\right), 4.24-4.36(2 \mathrm{H}, \mathrm{m}$, $\left.-\mathrm{OC}(=\mathrm{O}) \mathrm{O}-\mathrm{CH}_{2^{-}}\right)$.

12C-4EG: ${ }^{1} \mathrm{H} \mathrm{NMR}\left(300 \mathrm{MHz}, \mathrm{CDCl}_{3}\right): \delta=0.88(3 \mathrm{H}, \mathrm{t}, J=$ $\left.6.8 \mathrm{~Hz}, \mathrm{CH}_{3^{-}}\right), 1.18-1.48\left(18 \mathrm{H}, \mathrm{m},-\left(\mathrm{CH}_{2}\right)_{9^{-}}\right), 1.66(2 \mathrm{H}, \mathrm{tt}, J$ $\left.=7.1,7.1 \mathrm{~Hz},-\mathrm{CH}_{2}-\mathrm{CH}_{2}-\mathrm{O}-\right), 3.58-3.78\left(14 \mathrm{H}, \mathrm{m}, 7-\mathrm{CH}_{2}-\mathrm{O}-\right)$, $4.13\left(2 \mathrm{H}, \mathrm{t}, J=6.6 \mathrm{~Hz},-\mathrm{OC}(=\mathrm{O}) \mathrm{O}-\mathrm{CH}_{2^{-}}\right), 4.22-4.36(2 \mathrm{H}, \mathrm{m}$, $\left.-\mathrm{OC}(=\mathrm{O}) \mathrm{O}-\mathrm{CH}_{2^{-}}\right)$.

12C-3EG: ${ }^{1} \mathrm{H} \mathrm{NMR}\left(300 \mathrm{MHz}, \mathrm{CDCl}_{3}\right): \delta=0.88(3 \mathrm{H}, \mathrm{t}, J=$ $\left.6.8 \mathrm{~Hz}, \mathrm{CH}_{3^{-}}\right), 1.18-1.48\left(18 \mathrm{H}, \mathrm{m},-\left(\mathrm{CH}_{2}\right)_{9^{-}}\right), 1.66(2 \mathrm{H}, \mathrm{tt}, J$ $\left.=7.1,7.1 \mathrm{~Hz},-\mathrm{CH}_{2}-\mathrm{CH}_{2}-\mathrm{O}-\right), 3.58-3.80\left(10 \mathrm{H}, \mathrm{m}, 5-\mathrm{CH}_{2}-\mathrm{O}-\right)$, $4.15\left(2 \mathrm{H}, \mathrm{t}, J=6.6 \mathrm{~Hz},-\mathrm{OC}(=\mathrm{O}) \mathrm{O}-\mathrm{CH}_{2^{-}}\right), 4.25-4.36(2 \mathrm{H}, \mathrm{m}$, $\left.-\mathrm{OC}(=\mathrm{O}) \mathrm{O}-\mathrm{CH}_{2^{-}}\right)$.

12C-6EG: ${ }^{1} \mathrm{H} \mathrm{NMR}\left(300 \mathrm{MHz}, \mathrm{CDCl}_{3}\right): \delta=0.86(3 \mathrm{H}, \mathrm{t}, J=$ $\left.6.7 \mathrm{~Hz}, \mathrm{CH}_{3^{-}}\right), 1.14-1.52\left(18 \mathrm{H}, \mathrm{m},-\left(\mathrm{CH}_{2}\right)_{9^{-}}\right), 1.66(2 \mathrm{H}, \mathrm{tt}, J$ $\left.=7.1,7.1 \mathrm{~Hz},-\mathrm{CH}_{2}-\mathrm{CH}_{2}-\mathrm{O}-\right), 3.54-3.80(22 \mathrm{H}, \mathrm{m}$, $\left.11-\mathrm{CH}_{2^{-}} \mathrm{O}-\right), 4.14\left(2 \mathrm{H}, \mathrm{t}, J=6.4 \mathrm{~Hz},-\mathrm{OC}(=\mathrm{O}) \mathrm{O}-\mathrm{CH}_{2^{-}}\right)$, $4.22-4.32\left(2 \mathrm{H}, \mathrm{m},-\mathrm{OC}(=\mathrm{O}){\mathrm{O}-\mathrm{CH}_{2}-}^{-}\right)$.

\subsection{Preparation of ester-type nonionics containing polyoxyethylene chain}

Tetra (oxyethylene) dodecanoate (12Es-4EG) was prepared by the reaction of dodecanoyl chloride and tetra (ethylene glycol) in pyridine according to Scheme 2. That is, a mixture of dodecanoyl chloride $(6.0 \mathrm{mmol})$ and tetra (ethylene glycol) $(3.0 \mathrm{mmol})$ in pyridine $(36 \mathrm{~mL})$ was stirred under an argon atmosphere at $0^{\circ} \mathrm{C}$ for $30 \mathrm{~min}$. The mixture

Table 2 Synthesis and analytical data of $\mathrm{mC}-\mathrm{nEG}$

\begin{tabular}{cccccccc}
\hline \multirow{2}{*}{ Surfactant } & $\begin{array}{c}\mathrm{C}_{\mathrm{m}} \mathrm{H}_{2 \mathrm{~m}+1} \\
\mathrm{~m}\end{array}$ & $\begin{array}{c}\mathrm{HO}\left(\mathrm{CH}_{2} \mathrm{CH}_{2} \mathrm{O}\right)_{n} \mathrm{H} \\
\mathrm{n}\end{array}$ & $\begin{array}{c}\text { Yield } \\
(\%)\end{array}$ & \multicolumn{2}{c}{$\mathrm{C} \%$} & \multicolumn{2}{c}{$\mathrm{H} \%$} \\
\hline 8C-4EG & 8 & 4 & 72 & 58.03 & 58.26 & 9.74 & 9.78 \\
10C-4EG & 10 & 4 & 66 & 59.91 & 60.29 & 10.05 & 10.12 \\
$12 \mathrm{C}-4 \mathrm{EG}$ & 12 & 4 & 70 & 61.75 & 62.04 & 10.41 & 10.41 \\
$12 \mathrm{C}-3 \mathrm{EG}$ & 12 & 3 & 74 & 62.63 & 62.95 & 10.48 & 10.57 \\
$12 \mathrm{C}-6 \mathrm{EG}$ & 12 & 6 & 80 & 60.45 & 60.70 & 10.13 & 10.19 \\
\hline
\end{tabular}




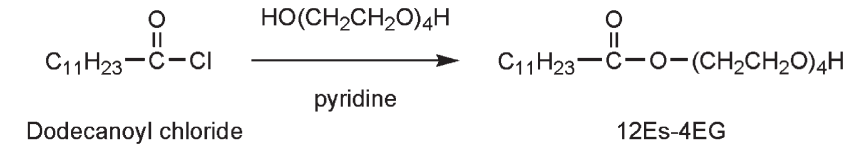

Scheme 2 Synthesis of 12Es-4EG

was then stirred at room temperature for $2 \mathrm{~h}$. After the reaction, the solvent was evaporated under reduced pressure. The residue was then purified by silica gel column $\operatorname{chromatography}\left(n\right.$-hexane/acetone $\left.=1 / 1, \mathrm{v} / \mathrm{v}, R_{f}=0.45\right)$ to obtain $12 \mathrm{Es}-4 \mathrm{EG}$ in $82 \%$ yield as a colorless syrup. The molecular structure was analyzed by ${ }^{1} \mathrm{H}$ NMR spectroscopy.

12Es-4EG: ${ }^{1} \mathrm{H} \mathrm{NMR}\left(300 \mathrm{MHz}, \mathrm{CDCl}_{3}\right): \delta=0.88(3 \mathrm{H}, \mathrm{t}, J=$ $\left.6.6 \mathrm{~Hz}, \mathrm{CH}_{3^{-}}\right), 1.17-1.39\left(16 \mathrm{H}, \mathrm{m},-\left(\mathrm{CH}_{2}\right)_{8^{-}}\right), 1.54-1.68(2 \mathrm{H}$, $\left.-\mathrm{CH}_{2}-\mathrm{CH}_{2}-\mathrm{O}-\right), 2.32\left(2 \mathrm{H}, \mathrm{t}, J=7.6 \mathrm{~Hz},-\mathrm{CH}_{2}-\mathrm{C}(=\mathrm{O}) \mathrm{O}-\right)$, 3.55-3.78(14H, m, 7- $\left.\mathrm{CH}_{2}-\mathrm{O}-\right)$, 4.18-4.27 (2H, m, -C $(=\mathrm{O})$ $\mathrm{O}-\mathrm{CH}_{2^{-}}$).

\subsection{Surfactant properties}

The static surface tension was measured using an Automatic Surface Tensiometer Model CBVP-Z (Kyowa Interface Science Co. Ltd., Tokyo, Japan) at $25^{\circ} \mathrm{C}$. The measurement was carried out using the Wilhelmy vertical plate technique and a sandblasted glass plate. The test solutions were aged at $25^{\circ} \mathrm{C}$ for at least $1 \mathrm{~h}$ prior to any measurements.

The occupation area of a molecule at a $\operatorname{surface}\left(A_{\min }\right)$ was calculated according to the Gibbs adsorption equation ${ }^{15)}$. The surface excess concentration $(\Gamma)$ in $\mathrm{mol} / \mathrm{m}^{2}$ and the corresponding $A_{\min }$ in $\mathrm{nm}^{2}$ at the liquid/air interface were calculated using Eqs. 1 and 2:

$$
\begin{aligned}
& \Gamma=\frac{-1}{2.30 \mathrm{RT}}\left(\frac{\mathrm{d} \gamma}{\mathrm{d} \log \mathrm{C}}\right) \\
& A_{\min }=\frac{10^{18}}{N_{A} \Gamma}
\end{aligned}
$$

where $d \gamma / d \log C$ is the slope of the surface tension vs. concentration curves below the $\mathrm{cmc}$ at a constant temperature, $\gamma$ is the surface tension in $\mathrm{mN} / \mathrm{m}$, T is the absolute temperature, $\mathrm{R}=8.31(\mathrm{~J} / \mathrm{mol} \mathrm{K})$, and $\mathrm{N}_{\mathrm{A}}$ is Avogadro's number.

Foaming properties were measured by the semi-micro TK method at $25^{\circ} \mathrm{C}$ according to Yano and Kimura ${ }^{16)}$. The initial foam volume was expressed as the foam production and the foam volume after 5 min represented foam stability.

\subsection{Hydrolytic stability}

A hydrolytic stability test was carried out by dissolving $12 \mathrm{C}-4 \mathrm{EG}$ and $12 \mathrm{Es}-4 \mathrm{EG}$ at $0.5 \mathrm{~g} / \mathrm{L}$ in distilled water at $30^{\circ} \mathrm{C}$ for $21 \mathrm{~d}$. Hydrolytic degradation of the nonionics was analyzed by SEC, and the hydrolytic stability was expressed as the remaining percent of surfactant.

\subsection{Biodegradation}

The biodegradabilities of the carbonate-type nonionics were evaluated by the biochemical oxygen demand (BOD). The BOD was determined with a BOD Tester (VELP Scientifica s.r.l., Usmate MI, Italy) using the oxygen consumption method according to the Modified MITI Test ${ }^{17)}$. Activated sludge was obtained from a municipal sewage plant in Yokohama city, Japan. The BOD-biodegradation (BOD/ThOD) was calculated from the BOD values and the theoretical oxygen demand (ThOD).

\subsection{Enzymatic degradation for chemical recycling}

The enzymatic degradation of mC-nEG was carried out using the immobilized lipase according to Scheme 1. The enzymatic degradation of 12C-4EG (20 mg) was carried out using $100 \mathrm{wt} \%$ immobilized lipase $\mathrm{CA}(20 \mathrm{mg})$ in toluene $(0.2 \mathrm{~mL})$ and $\mathrm{H}_{2} \mathrm{O}(2.0 \mu \mathrm{L}, 1.0 \mathrm{vol} \%$ relative to toluene $)$ at $50^{\circ} \mathrm{C}$ for $5 \mathrm{~d}$ with stirring. After the reaction, the immobilized lipase CA was removed by filtration, and the solvent was evaporated under reduced pressure. Purification was carried out by silica gel column chromatography ( $n$-hexane/acetone $\left.=3 / 1, \mathrm{v} / \mathrm{v}, R_{f}=0.50\right)$ to obtain the corresponding 1-dodecanol in $89 \%$ yield. The molecular structure of the degradation product was analyzed by ${ }^{1} \mathrm{H}$ NMR spectroscopy.

\section{RESULTS AND DISCUSSION}

\subsection{Synthesis of $\mathrm{mC}-\mathrm{nEG}$}

A series of mC-nEGs was prepared by the two-step carbonate exchange reaction of dimethyl or diphenyl carbonate and 1-alkanol followed by the reaction of the poly (ethylene glycol) using lipase or a chemical catalyst.

3.1.1 Enzymatic synthesis of mC-nEG using dimethyl carbonate

The mC-nEG was prepared by the two-step lipase-catalyzed carbonate exchange reaction of dimethyl carbonate and 1-alkanol followed by the reaction of the poly (ethylene glycol) as shown in Scheme 1. The lipase-catalyzed synthesis may be considered a green method because lipase is a renewable catalyst with high catalytic activity. First, various kinds of lipases were screened with respect to the carbonate exchange reaction of dimethyl carbonate with 1-dodecanol using lipase at $40^{\circ} \mathrm{C}$ for $24 \mathrm{~h}$. These results are summarized in Table 3. After the reaction, the unreacted dimethyl carbonate and methanol, which was produced as a condensate, were evaporated under reduced pressure. The compositions of the reaction products were calculated using ${ }^{1} \mathrm{H}$ NMR spectroscopy. Among the tested lipases, lipase CA showed the highest catalytic activity and was used for further studies. No significant reactivity was observed in the absence of lipase CA or using thermally deactivated lipase CA. Based on these results, lipase CA was responsi- 
Table 3 Carbonate exchange reaction of dimethyl carbonate with 1-dodecanol using various lipases

\begin{tabular}{|c|c|c|c|c|}
\hline \multirow[b]{2}{*}{ Entry } & \multirow[b]{2}{*}{ Lipase } & \multicolumn{3}{|c|}{ Composition } \\
\hline & & $\begin{array}{l}12 \mathrm{C}-\mathrm{Me} \\
(\mathrm{mol} \%)\end{array}$ & $\begin{array}{l}\text { Didodecyl carbonate } \\
(\mathrm{mol} \%)\end{array}$ & $\begin{array}{c}\text { Unreacted } \\
\text { 1-dodecanol (mol\%) }\end{array}$ \\
\hline 1 & Candida antarctica (lipase CA) & 61 & 12 & 27 \\
\hline 2 & Porcerin pancreas lipase (PPL) & 5 & 0 & 95 \\
\hline 3 & Candida rugosa (CR) & 2 & 0 & 98 \\
\hline 4 & Pseudomonas sp. (PS) & 0 & 0 & 100 \\
\hline 5 & Thermally deactivated lipase CA & 0 & 0 & 100 \\
\hline 6 & Blank & 0 & 0 & 100 \\
\hline
\end{tabular}

A mixture of dimethyl carbonate $(50.0 \mathrm{mg})$ and 1-dodecanol $(51.7 \mathrm{mg})$ in the presence of lipase $(10.2 \mathrm{mg})$ was stirred at $40{ }^{\circ} \mathrm{C}$ for $24 \mathrm{~h}$.

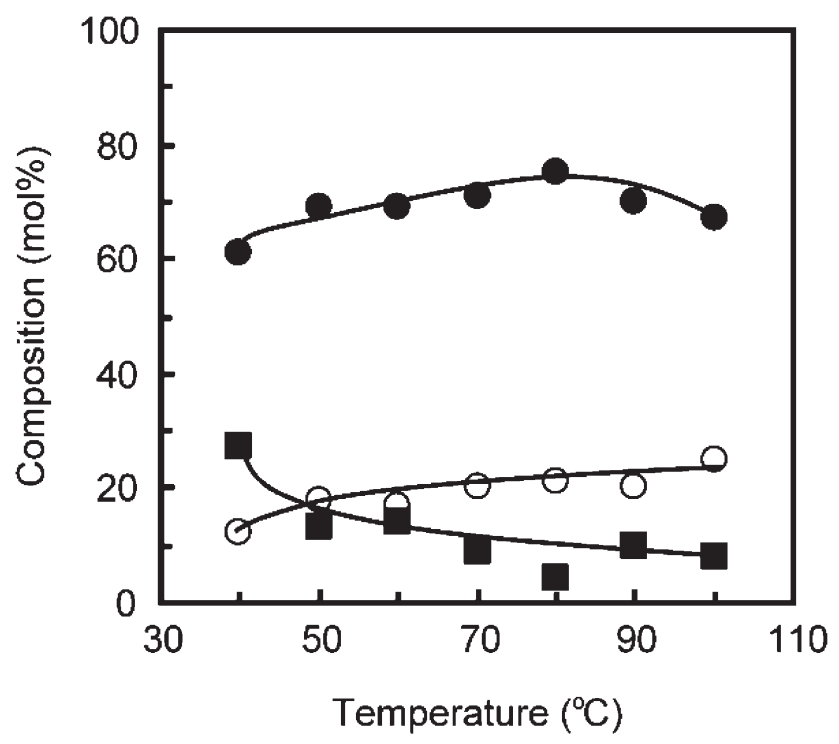

Fig. 1 Effects of temperature on the compositions of $12 \mathrm{C}-\mathrm{Me}(\mathrm{O})$, didodecyl carbonate $(\bigcirc)$, and 1-dodecanol ( $\square)$. Reaction conditions: dimethyl carbonate $(2.0 \mathrm{mmol}, 180.2 \mathrm{mg}), 1$-dodecanol (1.0 mmol, $186.3 \mathrm{mg})$, lipase CA (36.6 mg), $24 \mathrm{~h}$.

ble for the carbonate exchange reaction of dimethyl carbonate with 1-dodecanol.

Figure 1 shows the effects of temperature on the compositions of 12C-Me, didodecyl carbonate, and the unreacted 1-dodecanol for the carbonate exchange reaction of dimethyl carbonate and 1-dodecanol. The fraction of 12C-Me increased with increasing temperature from 40 to $80^{\circ} \mathrm{C}$ followed by a slight decrease with further increases in temperature. On the other hand, the fraction of didodecyl carbonate slightly increased with increasing temperature from 40 to $100^{\circ} \mathrm{C}$.

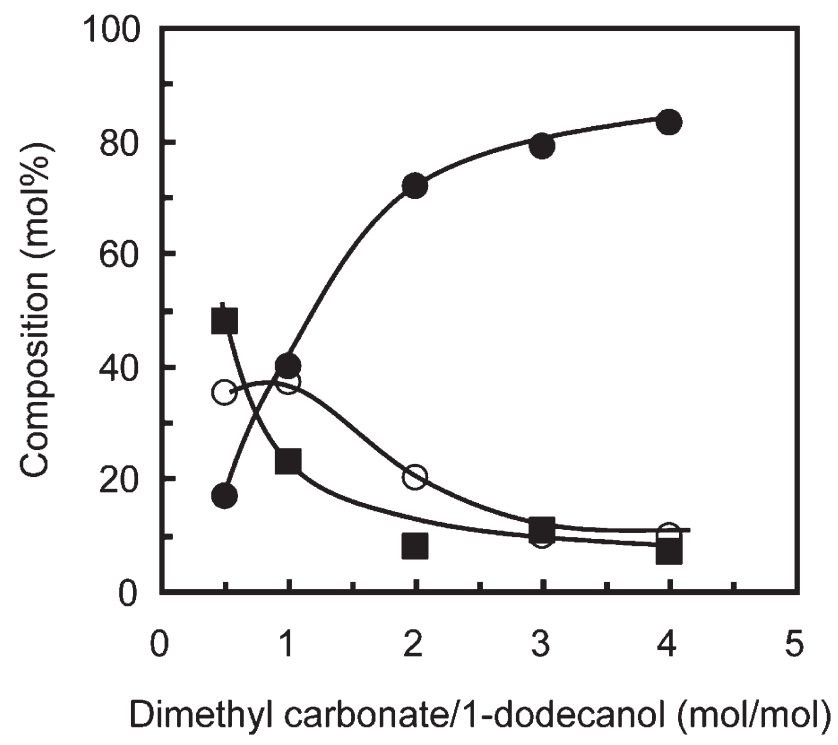

Fig. 2 Effects of molar ratio between dimethyl carbonate and 1-dodecanol on the compositions of $12 \mathrm{C}-\mathrm{Me}(\mathrm{O})$, didodecyl carbonate $(\bigcirc)$, and 1-dodecanol ( $\square$ ). Reaction conditions: lipase CA (10 wt $\%$ relative to both dimethyl carbonate and 1-dodecanol), $70^{\circ} \mathrm{C}, 24 \mathrm{~h}$.

Figure 2 shows the effects of the molar ratio of dimethyl carbonate and 1-dodecanol on the compositions of the reaction products. The fraction of didodecyl carbonate decreased with the increasing molar ratio from 1.0 to 3.0 $(\mathrm{mol} / \mathrm{mol})$. On the other hand, the fraction of $12 \mathrm{C}-\mathrm{Me}$ increased with the increasing molar ratio of dimethyl carbonate and 1-dodecanol. As a result, the maximum yield of $81 \%$ of $12 \mathrm{C}-\mathrm{Me}$ was obtained by the reaction of dimethyl carbonate (150 mmol) and 1-dodecanol (50 mmol) in the presence of lipase $\mathrm{CA}$ at $70^{\circ} \mathrm{C}$ for $24 \mathrm{~h}$. 
12C-4EG was prepared by the carbonate exchange reaction of 12C-Me and tetra (ethylene glycol). First, a mixture of 12C-Me (25 mmol), tetra (ethylene glycol) (50 mmol), and lipase CA $(1.6 \mathrm{~g})$ was stirred in bulk at $60^{\circ} \mathrm{C}$ and atmospheric pressure for $16 \mathrm{~h}$. Next, the reaction pressure was kept at $5 \mathrm{mmHg}$ in order to remove methanol as a condensate at $60^{\circ} \mathrm{C}$ for $8 \mathrm{~h}$. After the reaction, the lipase CA was removed by filtration, and the residue was then purified by silica gel column chromatography $(n$-hexane/acetone $=1 / 1$, $\left.\mathrm{v} / \mathrm{v}, R_{f}=0.55\right)$ to obtain $12 \mathrm{C}-4 \mathrm{EG}$ in $30 \%$ yield. The low yield of $12 \mathrm{C}-4 \mathrm{EG}$ was due to the decarboxylation of the carbonate linkage of $12 \mathrm{C}-\mathrm{Me}$ or $12 \mathrm{C}-4 \mathrm{EG}$ by lipase.

3.1.2 Synthesis of mC-nEG using diphenyl carbonate

The mC-nEG was prepared by the two-step carbonate exchange reaction of diphenyl carbonate and 1-alkanol followed by the reaction of poly (ethylene glycol). The 12C-Ph was prepared by the carbonate exchange reaction of diphenyl carbonate and 1-dodecanol in the presence of $\mathrm{Et}_{3} \mathrm{~N}$ at $70^{\circ} \mathrm{C}$ for $15 \mathrm{~h}$. On the other hand, its yield was only $11 \%$ when the reaction temperature was $80^{\circ} \mathrm{C}$. This is due to the formation of didodecyl carbonate.

The synthesis of $12 \mathrm{C}-4 \mathrm{EG}$ by the carbonate exchange reaction of $12 \mathrm{C}-\mathrm{Ph}$ and tetra (ethylene glycol) in the presence of $\mathrm{Et}_{3} \mathrm{~N}$ was investigated. Figure 3 shows the relationship between the yield of $12 \mathrm{C}-4 \mathrm{EG}$ and the molar ratio of tetra (ethylene glycol) over $12 \mathrm{C}-\mathrm{Ph}\left(\right.$ at $80^{\circ} \mathrm{C}$ for $48 \mathrm{~h}$ ). As a result, $12 \mathrm{C}-4 \mathrm{EG}$ was prepared in $64 \%$ yield by the reaction of $12 \mathrm{C}-\mathrm{Ph}(0.5 \mathrm{mmol})$ and tetra (ethylene glycol) (1.0 $\mathrm{mmol})$ in the presence of $\mathrm{Et}_{3} \mathrm{~N}(0.5 \mathrm{mmol})$ at $80^{\circ} \mathrm{C}$ for $48 \mathrm{~h}$.

In order to increase the yield of $12 \mathrm{C}-4 \mathrm{EG}$, the carbonate

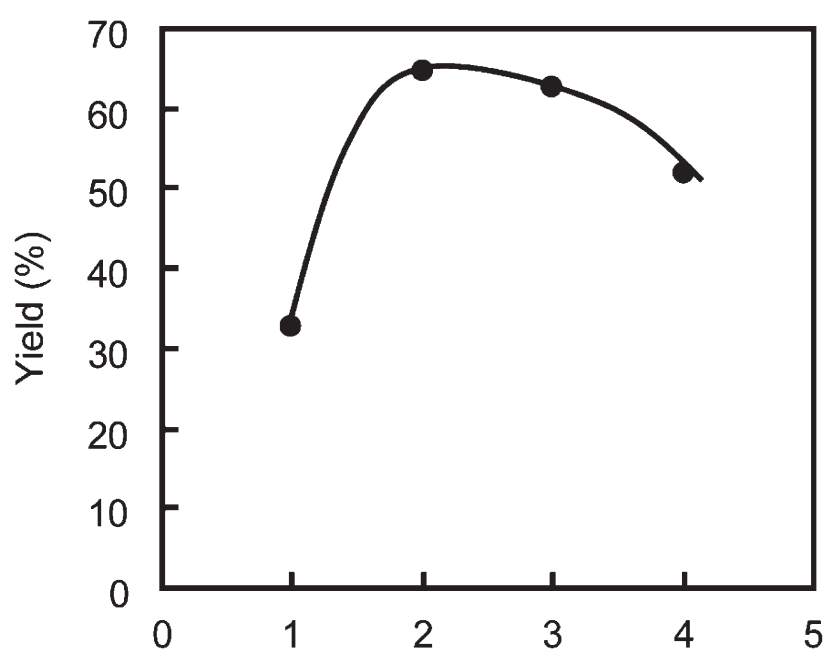

Tetra(ethylene glycol)/12C-Ph ( $\mathrm{mol} / \mathrm{mol})$

Fig. 3 Effects of molar ratio of tetra(ethylene glycol) and $12 \mathrm{C}-\mathrm{Ph}$ on the yield of $12 \mathrm{C}-4 \mathrm{EG}$. Reaction conditions: $12 \mathrm{C}-\mathrm{Ph}(1.0 \mathrm{mmol}), \mathrm{Et}_{3} \mathrm{~N}(1.0$ $\mathrm{mmol}), 80^{\circ} \mathrm{C}, 48 \mathrm{~h}$.

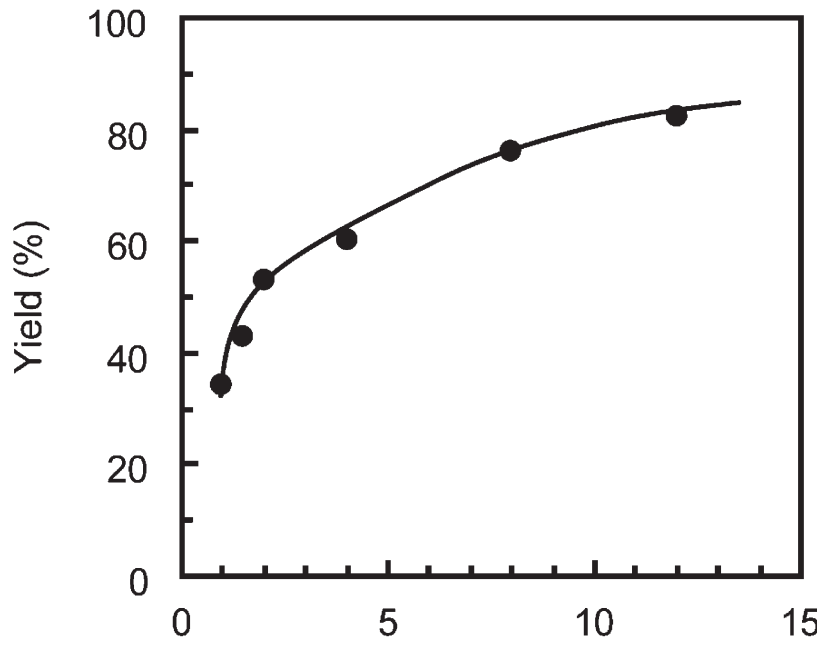

Tetra(ethylene glycol)/12C-Ph ( $\mathrm{mol} / \mathrm{mol})$

Fig. 4 Effects of molar ratio of tetra(ethylene glycol) and $12 \mathrm{C}-\mathrm{Ph}$ on the yield of $12 \mathrm{C}-4 \mathrm{EG}$ in bulk. Reaction conditions: $\mathrm{K}_{2} \mathrm{CO}_{3}(20 \mathrm{wt} \%$ relative to $12 \mathrm{C}-\mathrm{Ph}$ ), room temperature, $24 \mathrm{~h}$.

exchange reaction of $12 \mathrm{C}-\mathrm{Ph}$ and tetra (ethylene glycol) was carried out using lipase $\mathrm{CA}$ or $\mathrm{K}_{2} \mathrm{CO}_{3}$. We previously reported that di (iodoalkyl) carbonate was prepared by the carbonate exchange reaction of diphenyl carbonate and iodoalkanol using $\mathrm{K}_{2} \mathrm{CO}_{3}{ }^{18}$. A mixture of $12 \mathrm{C}-\mathrm{Ph}(0.5 \mathrm{mmol})$, tetra (ethylene glycol) $\left(1.0 \mathrm{mmol}\right.$ ), and lipase $\mathrm{CA}$ or $\mathrm{K}_{2} \mathrm{CO}_{3}$ (20 wt\% relative to $12 \mathrm{C}-\mathrm{Ph}$ ) was stirred at room temperature for $24 \mathrm{~h}$. The yield of 12C-4EG was $44 \%$ and 53\% when using lipase $\mathrm{CA}$ and $\mathrm{K}_{2} \mathrm{CO}_{3}$, respectively. The slightly lower yield from the lipase-catalyzed synthesis was due to the decarboxylation of the carbonate linkage of 12C-Ph or 12C-4EG during the reaction. Figure 4 shows the effect of the molar ratio of tetra (ethylene glycol) and 12C-Ph on the yield of $12 \mathrm{C}-4 \mathrm{EG}$ using $\mathrm{K}_{2} \mathrm{CO}_{3}$. The higher molar ratio tended to show a higher yield. The yield of 12C-4EG exceeded $80 \%$ when the molar ratio was $12(\mathrm{~mol} / \mathrm{mol})$. These results implied that the nucleophilic reactivity of the hydroxy group of the tetra (ethylene glycol) was relatively low. Further studies were carried out at a molar ratio of $2(\mathrm{~mol} / \mathrm{mol})$ by considering the atom economy (atom efficiency) ${ }^{19,20)}$.

The effect of solvent on the yield of 12C-4EG was also investigated when the concentration of 12C-Ph was 300 $\mathrm{mg} / \mathrm{mL}$. The yield of $12 \mathrm{C}-4 \mathrm{EG}$ was $53 \%$ in bulk. The yield increased by the addition of acetone. As a result, 12C-4EG was produced in $70 \%$ yield by the reaction of $12 \mathrm{C}-\mathrm{Ph}(0.5$ mmol) with tetra (ethylene glycol) $(1.0 \mathrm{mmol})$ in the presence of $\mathrm{K}_{2} \mathrm{CO}_{3}(20 \mathrm{wt} \%$ relative to $12 \mathrm{C}-\mathrm{Ph})$ in acetone at room temperature for $24 \mathrm{~h}$. In a similar procedure, mCnEG was prepared in 66-80\% yield as shown in Table 2. 
(a)

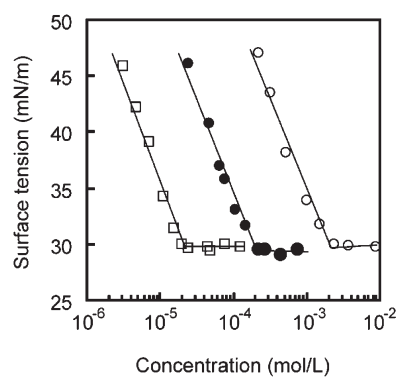

(b)

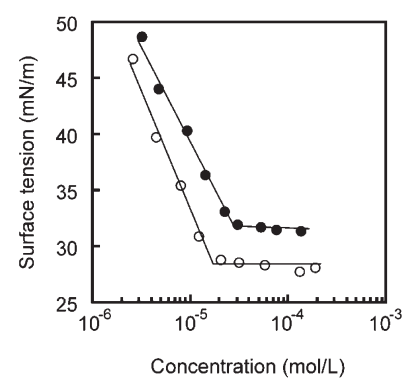

Fig. 5 Surface tension vs. concentration of $\mathrm{mC}-\mathrm{nEG}$ in aqueous solution at $25^{\circ} \mathrm{C}$. (a) $8 \mathrm{C}-4 \mathrm{EG}(\mathrm{O})$, 10C-4EG (○), 12C-4EG ( $\square$ ); (b) 12C-3EG $(\bigcirc), 12 \mathrm{C}-6 \mathrm{EG}(\bigcirc)$.

Table 4 Surfactant properties of carbonate, ester and ether-type nonionics in aqueous solution at $25^{\circ} \mathrm{C}$

\begin{tabular}{cccc}
\hline Surfactant & $\mathrm{cmc}(\mathrm{mM})$ & $\gamma_{\mathrm{cmc}}(\mathrm{mN} / \mathrm{m})$ & $10^{2} A_{\min }\left(\mathrm{nm}^{2}\right)$ \\
\hline 8C-4EG & 1.57 & 30.1 & 50.8 \\
10C-4EG & 0.173 & 29.5 & 49.2 \\
12C-4EG & 0.0191 & 29.5 & 44.7 \\
12C-3EG & 0.0153 & 28.8 & 42.1 \\
12C-6EG & 0.0288 & 31.8 & 56.0 \\
\hline 12Es-4EG & 0.0741 & 29.3 & 41.6 \\
12Et-4EG & 0.0551 & 29.2 & 47.7 \\
12Et-6EG & 0.110 & 31.3 & 66.7 \\
\hline
\end{tabular}

\subsection{Surfactant properties of $\mathrm{mC}-\mathrm{nEG}$ in aqueous solution}

The mC-nEG exhibited surface activities, such as surface tension lowering and micelle formation. Figure 5 shows the plots of surface tension vs. concentration curves of mC$n E G$ in an aqueous solution at $25^{\circ} \mathrm{C}$. From these plots, their $\mathrm{cmc}$, the surface tension at the cmc values $\left(\gamma_{\mathrm{cmc}}\right)$, and the $A_{\min }$ of the polyoxyethylene-type nonionics were determined and listed in Table 4. Table 4 also shows the surfactant properties of the ester and ether-type nonionics as a reference. It was found that the cmc values for the estertype $12 \mathrm{Es}-4 \mathrm{EG}$ and ether-type 12Et-4EG were roughly the same. These results implied that the carbonyl and methylene groups provide similar contributions to the surfactant properties. It is reported that the carbonyl groups of diester or monoester-type cationics can act as the hydrophobic moiety ${ }^{21,22)}$. It was also found that the cmc of the carbonate-type 12C-4EG was lower than the cmc of the ethertype 12Et-4EG. These results implied that the oxycarbonyl part of the carbonate linkage provides the same hydrophobic contribution as a methylene group. There existed a relationship between the alkyl chain length and the cmc, such that the addition of an extra methylene group decreased the cmc of the nonionics by a factor of three ${ }^{10)}$.

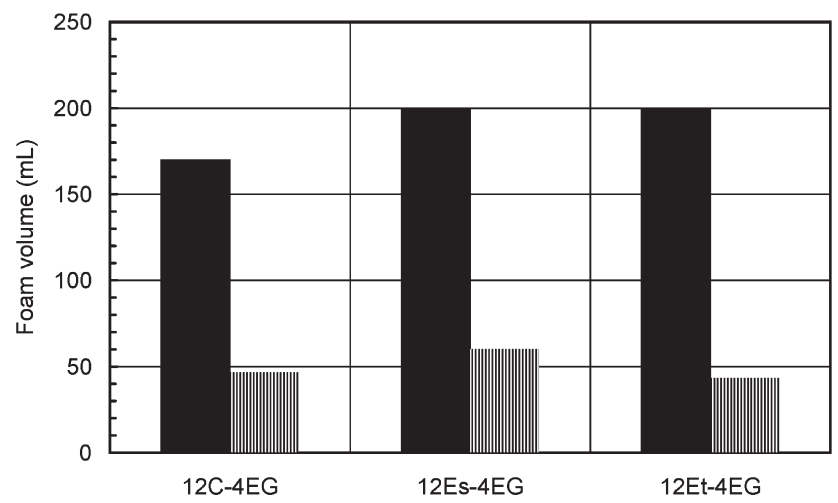

Fig. 6 Foam production and stability of carbonate, ester, and ether-type nonionics by semi-micro TK method in an aqueous solution (Sample concentration: $2.5 \mathrm{mM}$, temp.: $25^{\circ} \mathrm{C}$ ). Black: 0 min, stripe: $5 \mathrm{~min}$.

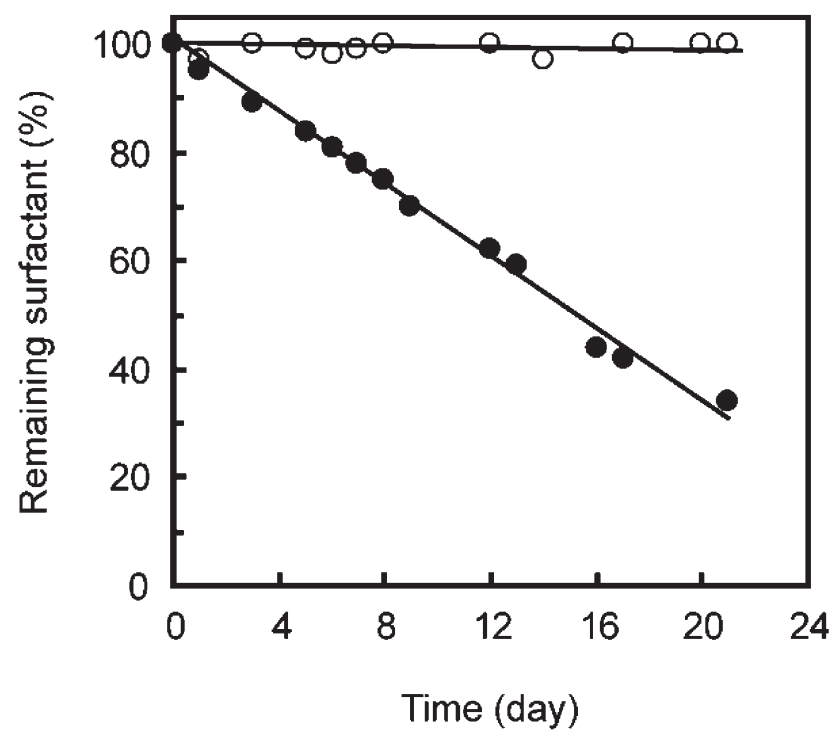

Fig. 7 Time course of hydrolytic degradation of carbonate-type 12C-4EG $(\bigcirc)$ and ester-type $12 \mathrm{Es}-4 \mathrm{EG}(\mathrm{O})$ at $0.5 \mathrm{~g} / \mathrm{L}$ in distilled water at $30^{\circ} \mathrm{C}$ for $21 \mathrm{~d}$.

Carbonate-type nonionics having a tetra (oxyethylene) chain had similar $\gamma_{\mathrm{cmc}}$ values. No significant differences in the $\gamma_{\mathrm{cmc}}$ values were observed among the linkages between the hydrophobic and hydrophilic moieties (cf. 12C-4EG, $12 \mathrm{Es}-4 \mathrm{EG}$, and 12Et-4EG). Among the tested carbonatetype nonionics containing an $n$-dodecyl group, the shorter oxyethylene chain tended to have a lower $\gamma_{\mathrm{cmc}}$ value. The lowest $\gamma_{\mathrm{cmc}}$ of 12C-3EG was due to the highest intermolecular hydrophobic interactions between the surfactant molecules. This is also supported by the results in which the shorter oxyethylene chain tended to have a lower $A_{\text {min }}$ val- 
ue.

The foaming properties of the nonionics containing a tetra (oxyethylene) chain were measured and compared at a concentration of $2.5 \mathrm{mM}$ (above the $\mathrm{cmc}$ ) using the semimicro TK method at $25^{\circ} \mathrm{C}^{16)}$. These results are summarized in Fig. 6. The tested carbonate, ester and ether-type nonionics showed a high foam production, but their stability was low. No significant differences in the foaming properties were observed by the linkages between the hydrophobic and hydrophilic moieties. This is due to the similar $A_{\text {min }}$ at the surface irrespective of the carbonate, ester, and ether linkages of the nonionics as shown in Table 4.

\subsection{Hydrolytic stability}

A hydrolytic degradation test was carried out by dissolving $12 \mathrm{C}-4 \mathrm{EG}$ and $12 \mathrm{Es}-4 \mathrm{EG}$ in distilled water at $30^{\circ} \mathrm{C}$. Figure 7 shows the time course of the hydrolytic degradation of the nonionics as measured by SEC. The carbonate linkage of $12 \mathrm{C}-4 \mathrm{EG}$ was stable in water, and $99 \%$ of the surfactant remained after $21 \mathrm{~d}$. On the other hand, the ester linkage of $12 \mathrm{Es}-4 \mathrm{EG}$ gradually hydrolyzed in water, and only $35 \%$ remained after $21 \mathrm{~d}$. The lower hydrolytic stability of $12 \mathrm{Es}-4 \mathrm{EG}$ was due to the autocatalysis caused by the production of the carbonic acid. Based on these results, it was confirmed that the carbonate-type $12 \mathrm{C}-4 \mathrm{EG}$ was more stable in water than the ester-type 12Es-4EG.

\subsection{Biodegradation}

The quick and complete biodegradation of surfactants

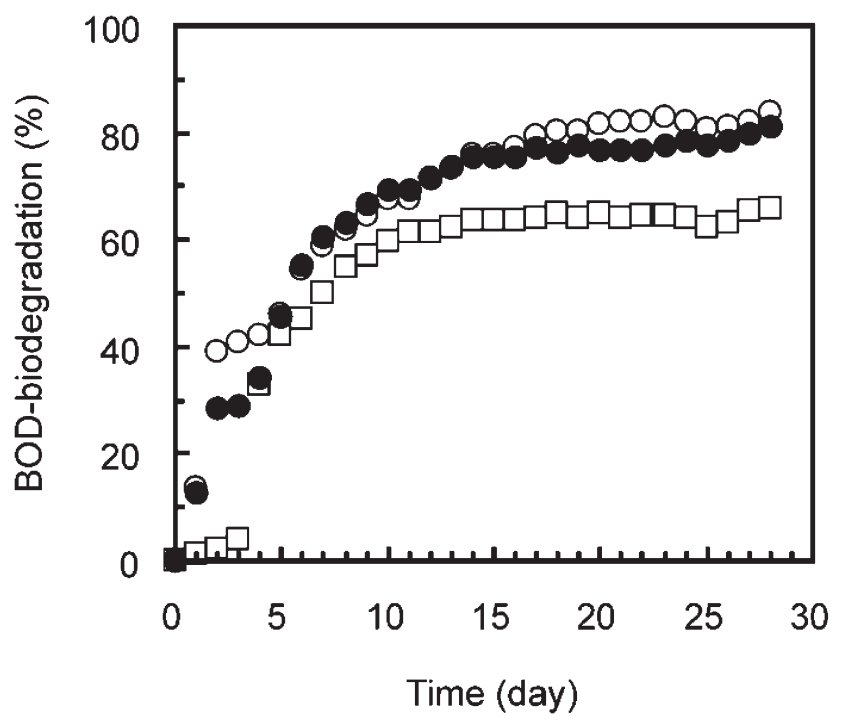

Fig. 8 Time courses of BOD-biodegradability of carbonate-type nonionics and aniline as a reference at $25^{\circ} \mathrm{C}$ for $28 \mathrm{~d}$. $12 \mathrm{C}-4 \mathrm{EG}(\mathrm{O})$; 12C-6EG $(\bigcirc)$; aniline $(\square)$. Activated sludge: $30 \mathrm{ppm}$, sample concentration: $80 \mathrm{ppm}$. after use is necessary to comply with green sustainable chemistry, because water-soluble household detergents are generally difficult to recover or reuse. The biodegradation of the synthesized nonionics containing carbonate linkages may first occur at the enzymatically hydrolyzable carbonate linkages by environmental microbes with the evolution of carbon dioxide forming low-molecular weight fragments. Further microbial assimilation of the primary degradation products then follows ${ }^{10)}$.

Figure 8 shows the time courses of the BOD-biodegradation $(\mathrm{BOD} / \mathrm{ThOD} \times 100)$ of $\mathrm{mC}-\mathrm{nEG}$ and aniline, as a reference. The tested carbonate-type nonionics were readily biodegraded by activated sludge. Their BOD-biodegradability exceeded $60 \%$ after a 28 d incubation, which is a criterion for acceptable biodegradation. No significant differences in the biodegradabilities of carbonate-type surfactants were observed by the oxyethylene chain.

\subsection{Enzymatic degradation and reproduction for chemical recycling}

In terms of green sustainable chemistry, even water-soluble surfactants should be chemically recycled, particularly in the industrial fields. The mC-nEGs were hydrolyzed by lipase and accompanied by carbon dioxide evolution to produce the corresponding 1-alkanol and poly (ethylene glycol), which could be converted into the initial nonionics by the reaction with dialkyl carbonate. Lipase-catalyzed chemical recycling may become a green method because lipase is a renewable catalyst with high catalytic activities. We previously reported that the single- and gemini-type cationics containing carbonate linkages were chemically recyclable using a lipase ${ }^{11,18)}$.

The enzymatic degradation of 12C-4EG was carried out in toluene containing a small amount of water using immobilized lipase CA. The 12C-4EG was completely degraded at the carbonate linkage to produce tetra (ethylene glycol) and 1-dodecanol as shown in Scheme 1. As discussed above, the 12C-4EG was reproduced by the two-step lipase-catalyzed carbonate exchange reaction of dimethyl carbonate and 1-dodecanol followed by the reaction of tetra (ethylene glycol). Based on these results, 12C-4EG showed a lipase-catalyzed chemical recyclability.

\section{CONCLUSION}

Green sustainable mC-nEGs were prepared by the twostep carbonate exchange reaction of dimethyl or diphenyl carbonate and 1-alkanol followed by the reaction of poly (ethylene glycol) in the presence of lipase or a chemical catalyst. They exhibited good surfactant properties in an aqueous solution. No significant differences in the foaming properties of the carbonate, ester, and ether-type nonionics were observed by the linkages between the hydropho- 
bic and hydrophilic moieties. The carbonate-type nonionics were more stable in water than the ester-type nonionics. Also, the $12 \mathrm{C}-n E G s$ were readily biodegraded by activated sludge. Furthermore, the carbonate-type nonionics were cleaved by lipase to produce the corresponding 1-alkanol and poly (ethylene glycol). They were then converted into the initial carbonate-type nonionics by the addition of dimethyl carbonate as a chemical recycling process.

\section{ACKNOWLEDGEMENT}

Immobilized lipase from Candida antarctica (lipase CA, Novozym 435) was kindly supplied by Novozymes Japan Ltd. (Chiba, Japan). This work was supported by a Grantin-Aid for General Scientific Research and JSPS Fellows 21 - 4882 from the Ministry of Education, Culture, Sports, Science, and Technology, Japan. This work was also supported by High-Tech Research Center Project for Private Universities: matching fund subsidy from MEXT, 2006-2011.

\section{References}

1) Okada, Y.; Banno, T.; Toshima, K.; Matsumura, S. Synthesis and properties of polycarboxylate-type green surfactants with $S$ - or $N$-linkages. J. Oleo Sci. 58, 519-528(2009).

2) Morán, C.; Pinazo, A.; Pérez, L.; Clapés, P.; Angelet, M.; García, T.; Vinardell, P.; Infante, R. "Green" amino acid-based surfactants. Green Chem. 6, 233-240 (2004).

3) Goursaud, F.; Berchel, M.; Guilbot, J.; Legros, N.; Lemiègre, L.; Marcilloux, J.; Plusquellec, D.; Benvegnu, T. Glycine betaine as a renewable raw material to "greener" new cationic surfactants. Green Chem. 10, 310-320 (2008).

4) Stjerndahl, M.; Holmberg, K. Synthesis and chemical hydrolysis of surface-active esters. J. Surfact. Deterg. 6, 311-318 (2003).

5) Stjerndahl, M.; Ginkel, C. G.; Holmberg, K. Hydrolysis and biodegradation studies of surface-active esters. $J$. Surfact. Deterg. 6, 319-324(2003).

6) Stjerndahl, M.; Holmberg, K. Synthesis, stability, and biodegradability studies of a surface-active amides. $J$. Surfact. Deterg. 8, 331-336(2005).

7) Tehrani-Bagha, A. R.; Oskarsson, H.; Ginkel, C. G.; Holmberg, K. Cationic ester-containing gemini surfactants: chemical hydrolysis and biodegradation. J. Colloid Interface Sci. 312, 444-452 (2007).

8) Tatsumi, T.; Zhang, W.; Kida, T.; Nakatsuji, Y.; Ono, D.; Takeda, T.; Ikeda, I. Novel hydrolyzable and biodegradable cationic gemini surfactants: 1,3-bis [ (acyloxyalkyl) dimethylammonio]-2-hydroxy- propane dichloride. J. Surfact. Deterg. 3, 167-172(2000).
9) Tatsumi, T.; Zhang, W.; Kida, T.; Nakatsuji, Y.; Ono, D.; Takeda, T.; Ikeda, I. Novel hydrolyzable and biodegradable cationic gemini surfactants: bis (ester-ammonium) dichloride having a butenylene or a butynylene spacer. J. Surfact. Deterg. 4, 279-285(2001).

10) Stjerndahl, M.; Holmberg, K. Hydrolyzable nonionic surfactants: Stability and physicochemical properties of surfactants containing carbonate, ester, and amide bonds. J. Colloid Interface Sci. 291, 570-576 (2005).

11) Banno, T.; Toshima, K.; Kawada, K.; Matsumura, S. Synthesis and properties of biodegradable and chemically recyclable cationic surfactants containing carbonate linkages. J. Oleo Sci. 56, 493-499 (2007).

12) Choi, J.; He, L.; Yasuda, H.; Sakakura, T. Selective and high yield synthesis of dimethyl carbonate directly from carbon dioxide and methanol. Green Chem. 4, 230-234 (2002).

13) Hou, Z.; Han, B.; Liu, Z.; Jiang, T.; Yang, G. Synthesis of dimethyl carbonate using $\mathrm{CO}_{2}$ and methanol: enhancing the conversion by controlling the phase behavior. Green Chem. 4, 467-471 (2002).

14) Fujita, S.; Bhanage, B.; Ikushima, Y.; Arai, M. Synthesis of dimethyl carbonate from carbon dioxide and methanol in the presence of methyl iodide and base catalysts under mild conditions: effect of reaction conditions and reaction mechanism. Green Chem. 3, 87-91 (2001).

15) Kwan, C. C.; Rosen, M. J. Relationship of structure to properties in surfactants 9. Synthesis and properties of 1,2- and 1,3-alkanediols. J. Phys. Chem. 84, 547-551 (1980).

16) Yano, W.; Kimura, W. Studies on the evaluation methods of surface active agents 2. Foam test: semimicro improved TK-method. J. Jpn. Oil Chem. Soc. 11, 138-144(1962).

17) OECD guidelines for testing of chemicals, 301C, modified MITI test. Organization for Economic Cooperation and Development (OECD). Paris (1981).

18) Banno, T.; Toshima, K.; Kawada, K.; Matsumura, S. Synthesis and properties of gemini-type cationic surfactants containing carbonate linkages in the linker moiety directed toward green and sustainable chemistry. J. Surfact. Deterg. 12, 249-259(2009).

19) Trost, B. M. Atom economy-a challenge for organic synthesis: Homogeneous catalysis leads the way. Angew. Chem. Int. Ed. Engl. 34, 259-281 (1995).

20) Trost, B. M. The atom economy-a search for synthetic efficiency. Science 254, 1471-1477 (1991)

21) Rozycka-Roszak, B.; Przestalski, S.; Witek, S. Calorimetric studies of the micellization of some amphiphilic betaine ester derivatives. J. Colloid Interface Sci. 125, 80-85 (1988).

22) Menger, F. M.; Galloway, A. L. Contiguous versus segmented hydrophobicity in micellar systems. J. Am. 


\section{T. Banno, H. Sato, T. Tsuda and S. Matsumura}

Chem. Soc. 126, 15883-15889 (2004).

23) Sagoh, T.; Toshima, K.; Kawada, K.; Matsumura, S. Enzymatic synthesis of surface active and biodegradable glucosaminide fatty acid esters. J. Oleo Sci. 52, 597-606 (2003). 